\title{
Soaring House Prices Reflect a Shortage of Homes Rather than a New Housing Bubble
}

\author{
Peter L. D’Antonio, Ph.D. \\ Molloy College \\ School of Business \\ 1000 Hempstead Avenue \\ Rockville Centre, NY 11571 \\ USA
}

\begin{abstract}
Home prices have soared by 58 percent during the past seven years and now stand 15 percent above boom-time highs. Although this steep rise is reminiscent of last decade's housing bubble, the root cause is very different and implies a sharply divergent path for the housing market in coming years. The price rise during the housing boom was a symptom of excesses in housing. In contrast, the current price rise signals the need for more construction as the market faces growing shortages. This paper introduces a new housing supply metric to show that the massive overbuilding during the housing boom set in motion an extended period of underbuilding that is still ongoing ten years after the recession ended. The current housing underbuilding explains the recent price rise, and the new metric suggests that construction activity and prices will continue to increase.
\end{abstract}

Keywords: home prices, housing bubble, home construction, household formation

\section{Introduction - Shortage-Led Price Rise, Not a Bubble}

The housing boom was a classic bubble in the Shiller (2013) sense - people believed the narrative that home prices could never decline. With that belief, they viewed investment in homes as a one-sided bet. This mindset induced homebuyers and homebuilders to jump into the market, fueling housing construction and more house price appreciation. This drove prices well above any reasonable sense of their intrinsic value.

Figure 1 shows that the current rise in home prices looks similar to the rise during the boom. However, the supply characteristics of the housing market are markedly different now, suggesting that the current price rise is not a bubble. The analysis in this paper, using the new housing supply metric, shows that the housing overbuilding during the boom period reached nearly two and a half million units, but the subsequent underbuilding has more than eliminated the housing surplus, leaving the market in short supply today and driving up home prices.

\section{Motives for Building New Homes}

The housing market can be viewed as two separate markets: (1) The current stock of housing that is occupied by current homeowners and renters and comprises the existing home market. When the stock of homes is in balance with the need for homes, it should be the case that most households would be able to find housing (either to own or rent) from the existing housing stock. (2) Additions to the housing stock represent the new home market. New homes would be needed, for example, in an economy with an expanding population. This paper focuses on the second of these markets - the supply of and demand for new homes.

There are several reasons that the stock of homes would not match the need for homes, giving rise to increased or decreased demand and the building of new homes. The main factor driving homebuilding is demographic - changes in the number of people forming new households. In addition, there may be small changes in the number of households that wish to have second homes. The housing stock may also be affected by other factors, such as demolitions, reconfigurations, damage or conversions (Schuetz and Murray, 2018). The resulting construction of new homes would be expected to drive the housing stock toward the level of the need for housing.

There is another important motive for building new homes that is not based solely on need. Homes not only offer the owner a place to live, but also serve as key investment assets (Weintraub, 2019). For instance, the stunning rise in home prices during the housing boom (1995-2005) accentuated this motive for owning a home. When prices were rising rapidly, people saw homes as a lucrative investment. As a result, the demand for homes far surpassed the current housing stock at the time. To satisfy the excess demand, homebuilders ramped up new home construction. Homebuilders also increased the number of homes they built for speculative reasons (Figure 2). 
The outsize demand during the boom drove up prices and set in motion a surge in home construction that, in turn, created a massive housing glut. That oversupply of homes has dampened housing construction for the past decade. Too many available homes and rising vacancies inevitably caused home prices to fall starting in 2005, which in turn caused the investment motive for owning homes to dry up. However, by that time, there already were far too many houses in existence relative to the need for housing.

\section{Housing Need (Demand) and Construction Activity (Supply)}

This paper looks at the supply of homes since 1995 (the year the housing boom started) to gauge the health and direction of the housing market. Specifically, this study compares the needs of households (as dictated by the pace of household formation) with new home construction over time. Conerly (2018) moves in this direction by comparing construction with population growth to say that the US continues to underbuild new homes. However, he stops short of using year-by-year comparisons to form a view of the relative supply (stock) and demand (need) for houses over time. This paper accumulates the excesses and shortages to determine the adjustment that would be needed to restore balance between the housing stock and housing need at any time.

3.1 Housing Need (Demand). As Figure 3 shows, new housing need hovered at a pace of about 1.4 million units per year from 1995 through 2003 (Census [3], 2019). Household formation was the main driver of how many additional housing units would be needed to satisfy new demand. In addition, home depletions (demolitions and damaged homes), changes in demand for second homes, reconfigurations, and conversions are assumed to have added about 250 thousand units per year to the overall housing need.

Household formation increased briefly around the end of the housing boom (2005-07), but that trend reversed quickly. The recession and subsequent weak economy caused household formation to crater from 2008 to 2011. Many people in their 20s and 30s either could not find work at all or found jobs with pay that was not commensurate with their education, so fewer could afford to buy or rent homes than in the past. Instead, they continued to live with their parents (Fry, 2016). As a result, overall housing need dropped to about 850 thousand per year (see Figure 3). Since 2014, household formation has rebounded, and new housing need have reached normal levels of around 1.4 million per year.

3.2 Construction Activity (Supply). Housing construction soared during the housing boom, from 1995 to 2005. The pace of home construction peaked at 2 million per year at the height of the boom (Census [1], 2019), well beyond new housing need. This overbuilding was a result of the bubble mentality that took hold of the housing market at that time. Price rises were met by more overbuilding. The excess supply can be seen in Figure 3 as the gap between the housing construction and housing need lines.

This elevated pace of building did not last, however. After the housing bubble burst, new home construction plummeted by about 75 percent to less than 600 thousand units per year by the end of 2010 (Census [1], 2019). That drop was much steeper than the actual decline in household formation. The net result was serious underbuilding of new homes by 2011. This underbuilding continues today despite a rebound in new home construction in recent years.

Figure 4 shows relative changes in new home need and housing construction, highlighting the overbuilding and underbuilding over the past two and a half decades. These data match the average values for selected periods in Figure 3. The dates in Figure 4 roughly conform to the major shifts in housing need and construction.

\section{The New Housing Metric}

This paper introduces a new excess housing supply metric. The metric can be used to assess the current state of the housing market at any particular time by comparing the additions of new homes over time to the rise in housing need. For example, the metric quantifies the excess supply that occurred during the boom period by taking the differences between housing construction and new home need each year and cumulating them over time. The metric also tracks the progress toward rebalance during the pullback in home construction from 2008 to 2011 and the rebound in construction since then.

The formula for this new metric $S_{t}$, signifying excess supply at time $t$, is

$\mathrm{S}_{\mathrm{t}}=\sum($ Construction $(\mathrm{t})-\operatorname{Need}(\mathrm{t}))$

where the sum is taken from an initial point prior to the housing boom to time t. For this study, the initial point is 1995, when the housing boom began.

\section{Results - From Surplus to Shortage}

As shown in the period overbuilding line in Figure 4, housing need and construction were roughly in balance through 1999. However, during the period from 2000 to 2007, there were far too many homes completed relative to need. 
The last line in Figure 4 presents the new housing supply metric, $S_{t}$, representing the cumulative overbuilding to time $t$. This metric shows a massive glut of more than 2 million homes during the boom.

The metric also shows that the housing market correction more than eliminated the glut during the period from 2012 to the present, and actually generated a new shortage of homes. Since housing construction continues to undershoot housing need, construction activity is likely to continue to increase along with home prices in coming years.

Figure 5 shows a year-by-year estimate of the size of the cumulative housing glut, as measured by $\mathrm{S}_{\mathrm{t}}$. According to this metric, the surplus reached nearly 2.5 million homes at the worst point of the housing crash in 2009 . The excess supply continued to rise despite the drop off in construction because housing need was even lower. The huge glut of homes led many analysts at the time to believe that home prices and the housing market would never improve (for example, Hough, 2012).

The size of the boom-time overbuilding determined how long and deep the subsequent underbuilding would have to be for the housing market to be restored to a healthy balance. For example, underbuilding of 500 thousand units per year would take five years to correct the 2.5 million cumulative excess. These conditions essentially set in motion the correction that has lasted for the entirety of the current expansion.

According to Figure 5, the new metric returned to neutral by 2017, which is consistent with the roughly 350 thousand unit annual average underbuilding in the prior seven years. But the underbuilding did not stop there. Even today, builders remain cautious about "working on spec" and bankers are stingy with loans to builders (Coy, 2019).

The running rate of construction continues to be well below new housing need. As a result, each year the stock of houses has drifted lower relative to need. By the end of 2019, the new supply metric showed a 782 thousand unit shortage of houses, which seems to mirror the path of housing vacancies over time. The latest readings show that the shortage of homes corresponds to historically low vacancies (Census [4], 2019).

\section{Conclusion - Supply Metric Contrasts Price Gains}

The price rise during the housing bubble was fueled by surging investment demand based on a mistaken perception that house prices could never decline. Homebuilding soared to satisfy this investment demand, and prices increased in the process, as homebuilders and buyers became more convinced that housing was a profitable investment. In effect, the excess supply was a result of the rise in price. The excess supply metric provides an estimate of the peak excess supply of 2.5 million units that developed during this time.

The current rise in price stands in sharp contrast to the price rise during the housing boom. During the current expansion, supply has persistently fallen short of need. The rise and fall of the housing supply metric highlight this important difference. Persistent underbuilding of new homes put upward pressure on prices over the past decade, and the current growing shortage of homes suggests that home prices will continue to appreciate. Moreover, consistent with the message from the excess supply metric, this rise in home prices acts a signal to the housing market that there is more need for supply.

Based on the excess supply metric, home construction must increase further just to stop the new shortage of houses from becoming more acute and exerting even greater upward pressure on home prices. To reestablish balance in the housing market, home construction would have to rise well beyond need for the next several years. 


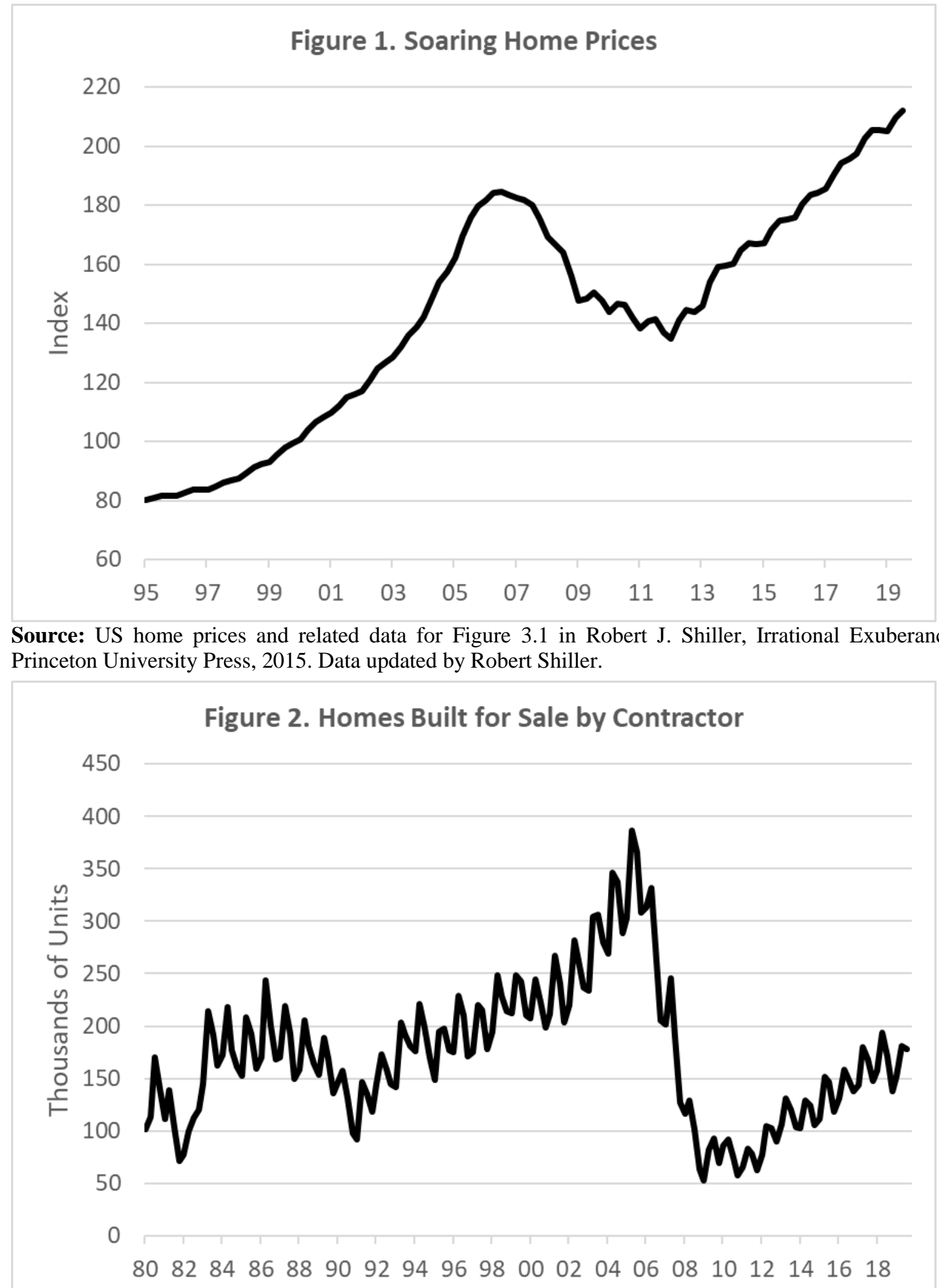

Note: Built for sale (or speculatively built) - means the builder is offering the house and the developed lot for sale as one transaction. Source: Census Bureau [2], Housing Starts by Purpose. 


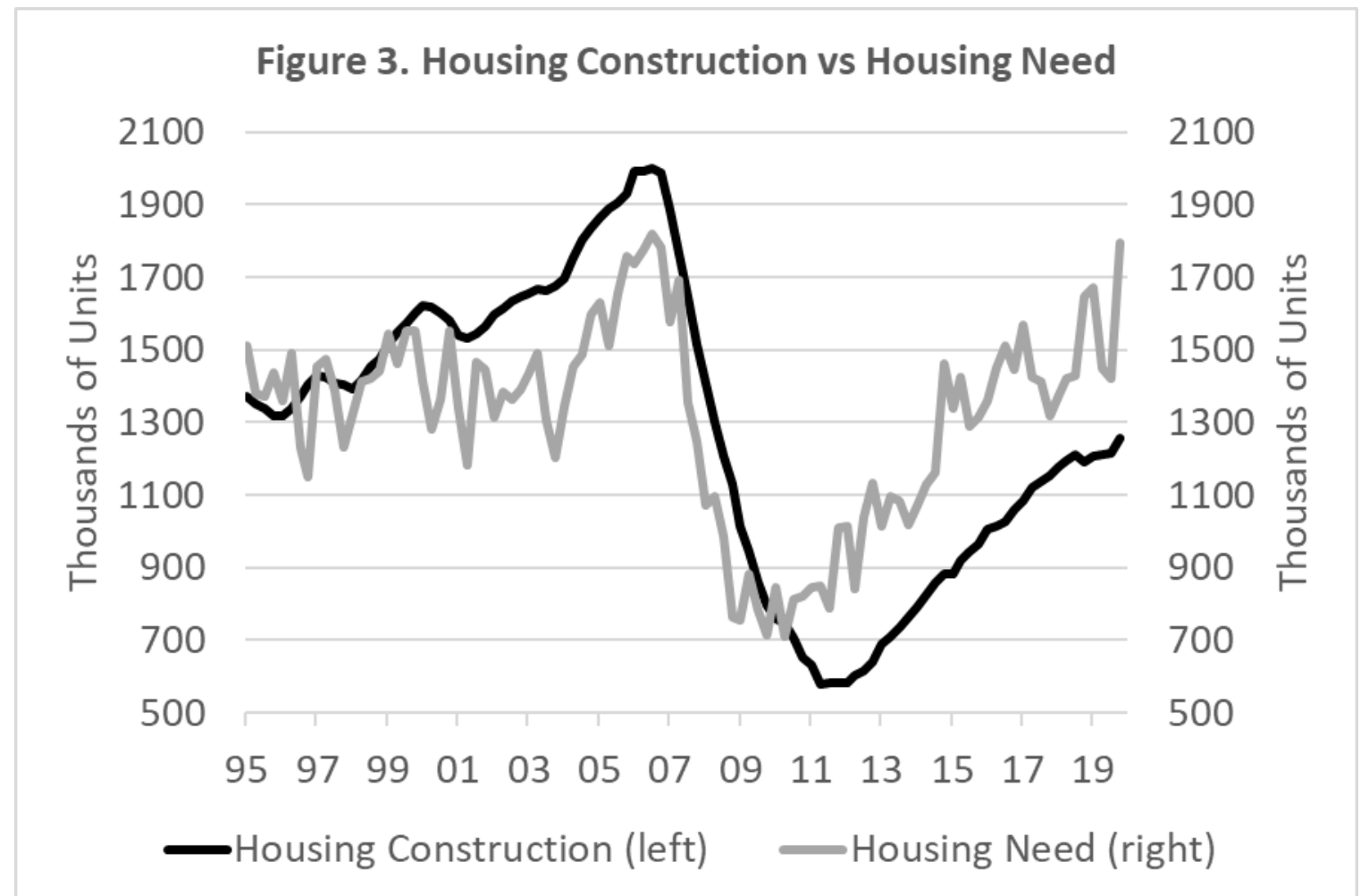

Note: Data are reported quarterly at annual rates. Housing construction is measured by the number of new home completions. Sources: Census Bureau [3], Housing Inventory; Census Bureau [1], Residential Construction.

Figure 4. Household Construction vs Housing Need

Household Formation

Other Factors

Total Housing Need

Construction

Yearly Avg Overbuilding

Period Overbuilding (Total)

Cumulative Overbuilding (Total)
1995-992000-072008-112012-19

$\begin{array}{rrrr}1159 & 1229 & 608 & 1066 \\ \frac{250}{1409} & \frac{250}{1479} & \underline{250} & \frac{250}{858} \\ 1423 & 1725 & 869 & 1316 \\ & & & 958\end{array}$

14

70
70$$
246
$$

$2038 \quad 1968$

11

2082
1066

$\frac{250}{1316}$

958

$-2864$

Notes: Data are annual averages unless noted. Period Overbuilding (Total) represents the sum of the overbuilding during each period, and Cumulative Overbuilding gives the sum of the periods. Negative values denote underbuilding. Sources: Census [3], Housing Inventory, Census [1], Residential Construction. 


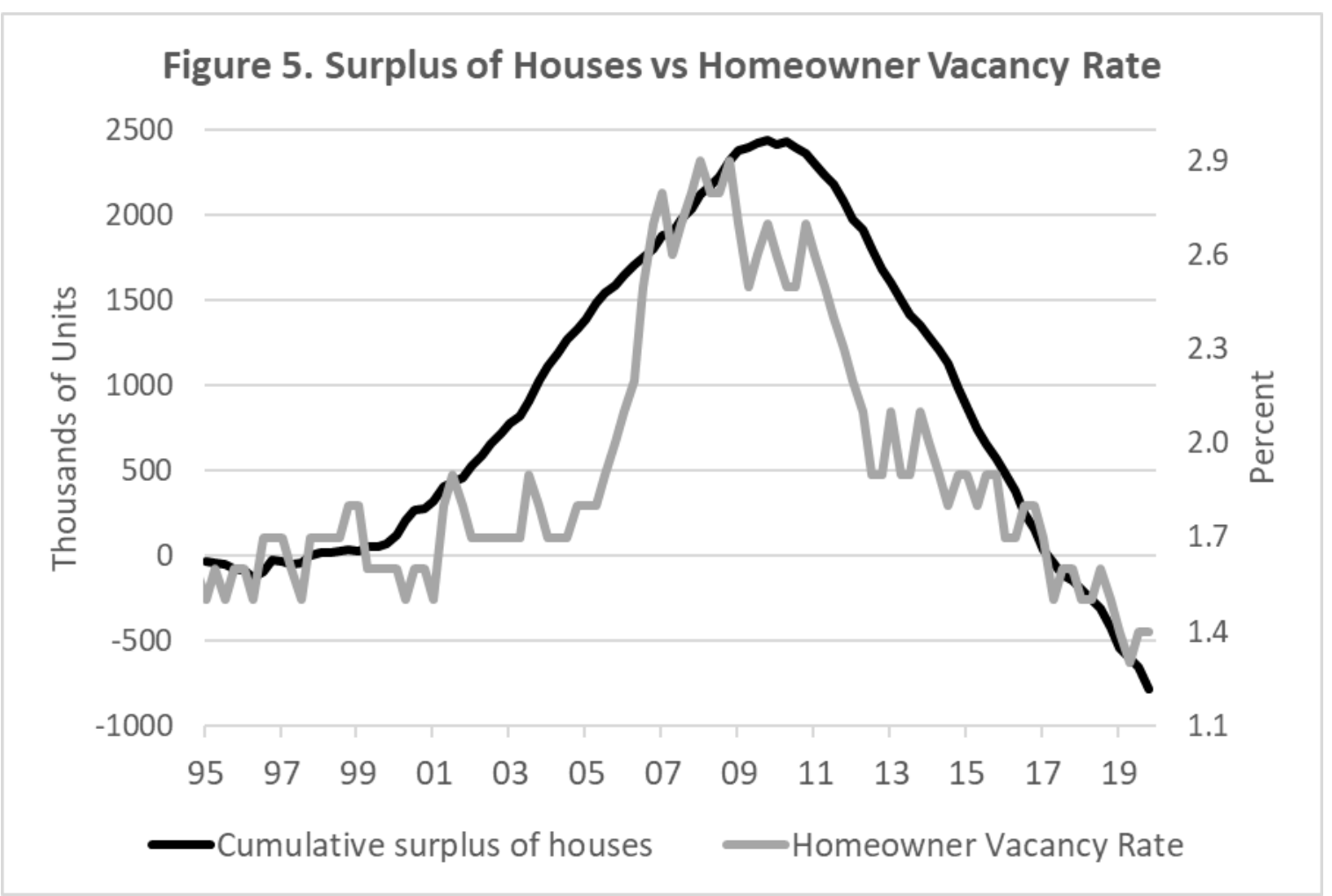

Note: Data are reported quarterly at annual rates. Sources: Census Bureau [3], Inventory, Census Bureau [1], Residential Construction, and Census Bureau [4], Vacancy Rates.

\section{References}

Census Bureau [1] (2020). New Residential Construction, Table 5. Updated January 17, 2020.

Census Bureau [2] (2019). New Privately Owned Housing Units Started by Purpose and Design, Table Q1. Updated November 19, 2019.

Census Bureau [3] (2019). Estimates of Housing Inventory, Table 4. Updated January 30, 2020.

Census Bureau [4] (2019). Vacancy Rates for the US, Table 1. Updated January 30, 2020.

Conerly, B. (2019). Housing Forecast: Not a Bubble in 2019. Forbes, November 3, 2018.

Coy, P. (2019). The Long Reach of the Last Crash. Real Estate Section. Bloomberg Businessweek, February 18, 2019.

D’Antonio, P. (2019). Housing Market Follows Elongated Supply Cycle. Northeast Business and Economics Association. 2019 Conference and Proceedings. November 2019.

Eggers, F. and Moumen, F. (2016). Components of Inventory Change: 2011-2013, American Housing Survey. US Department of Housing and Urban Development, Office of Policy Development and Research. April 2016.

Fry, R. (2016). For First Time in Modern Era, Living with Parents Edges Out Other Living Arrangements for 18- to 34Year Olds. Pew Research Center, Social and Demographic Trends. May 24, 2016.

Haver Analytics, Inc. provided the data for this paper.

Hough, J. (2012). Why US House Prices Won't Recover. MarketWatch, May 1, 2012.

Schuetz, J. and Murray, C. (2018). Unpacking the "housing shortage" puzzle: How does housing enter and exit supply? Brooking, April 25, 2018.

Shiller, R. (2013). Speculative Asset Prices, Nobel Prize Lecture, Stockholm, Sweden, December 8, 2013.

Shiller, R. (2015). Irrational Exuberance, Third Edition. Princeton University Press, 2015. Updated November 27, 2019.

Weintraub, E. (2019). Eight Reasons to Buy a Home. The Balance, May 14, 2019. 